\title{
Epstein-Barr Virus Infection Reactivation, CTCAE
}

National Cancer Institute

\section{Source}

National Cancer Institute. Epstein-Barr Virus Infection Reactivation, CT CAE. NCI

Thesaurus. Code C143208.

A disorder characterized by the reactivation of Epstein-Barr virus (EBV). 